Surfer Girls in the New World Order 


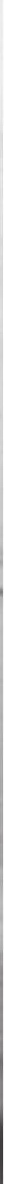




\title{
Surfer Girls in the New World Order
}

\section{Krista Comer}

\author{
Duke \\ University \\ Press
}

Durham \&

London 2010 
(c) 2010

Duke University Press

All rights reserved

Printed in the

United States of America

on acid-free paper $\infty$

Designed by Jennifer Hill

Typeset in Theserif by

Tseng Information Systems, Inc.

Library of Congress

Cataloging-in-Publication

Data appear on the last

printed page of this book. 
For my father 
